\title{
HUBUNGAN ASUPAN KALSIUM DAN FOSFOR, INDEKS MASSA TUBUH, PERSEN LEMAK TUBUH KEBIASAAN OLAHRAGA, USIA AWAL MENSTRUASI DENGAN KEPADATAN TULANG PADA REMAJA PUTRI
}

\author{
Meidi L Maspaitella, Fillah Fithra Dieny ${ }^{*}$ \\ Program Studi Ilmu Gizi Fakultas Kedokteran Universitas Diponegoro \\ Jl.Dr.Sutomo No.14, Semarang, Telp (024) 8453708, Email : gizifk@undip.ac.id
}

\begin{abstract}
Background : Adolescent is a growth spurt period, so that nutrient needs is increases. However that fact shows severe adolescent have low bone density. Because that low intake of minerals (calcium and phosphorus), less in exercise, high or low body mass and abnormal menarche age .

Objective : To indentify correlation between body mass index, percent body fat, exercise frequency, menarche age, calcium and phosphor intake with bone density in female high school student.

Method : Design of this study is cross sectional with 74 subject which selected by proportional stratified random sampling. Analyzed data were body mass index which obtained by bio impedance analyzer and microtoise, exercise frequency, menarche age, calcium and phosphorus intake which obtained by questionnaire through interview, and also bone density which obtained by densitometer. Bivariate analyzed by rank spearman correlation.

Result : subjects age were 14 to 18 years. 28,4\% subjects were osteopenia. Based on z score, there were 1,4\% subject with severe underweight, 13,5\% subject with underweight, 6,8\% subject with overweight, and 2,7\% subject with obesity. Based on percent body fat, there were $28,4 \%$ subject with underfat and 9,5\% subject with obesity. Almost subject were less in exercise which can increrase bone density. 16,2\% subjects have an abnormal menarche age. 93,2\% subjects have low calcium intake and 40,5\% subjects have high phosphorus intake. Bivariate analyzed showed high body mass index was associate with low bone density in female adolescent $(r=-0,231 \quad p=0,047)$. However there is no significant correlation between other factors, such percent body fat $(r=-0,124 p=0,293)$, exercise frequency $(r=0,106 p=0,368)$, menarche age $(r=-0,052 p=0,660)$, calcium $(r=0,089 p=0,452)$ and phosphorus intake $(r=0,087 p=0.463)$ with bone density.
\end{abstract}

Conclusion : there was correlation between body mass index with bone density.

Key word : female adolescent; bone density; body mass index; percent body fat; exercise frequency; menarche age; calcium intake; phosphorus intake

\begin{abstract}
ABSTRAK
Latar belakang : Remaja merupakan periode growth spurt sehingga kebutuhan zat gizi meningkat. Namun kenyataan beberapa remaja memiliki kepadatan tulang yang rendah hal ini disebabkan antara lain: asupan kalsium dan fosfor yang tidk seimbang, aktivitas olahraga yang kurang, kelebihan atau kekurangan berat badan serta terlambat menstruasi.

Tujuan : Mengindentifikasi hubungan antara indeks massa tubuh, persen lemak tubuh, kebiasaan olahraga, usia awal menstruasi, asupan kalsium, dan asupan fosfor dengan kepadatan

Metode : Desain penelitian cross sectional dengan jumlah subjek 74 anak dipilih secara proportional stratified ramdom sampling. Data yang diteliti meliputi indeks massa tubuh (IMT), persen lemak tubuh yg diukur dengan Bio Impedance Analyzer dan microtoice, kebiasaan olahraga, usia awal menstruasi, asupan kalsium dan fosfor diukur melalui wawancara dengan kuesioner dan food frequency questionnaire dan food recall serta kepadatan tulang diukur dengan Densitometer. Analisis bivariat menggunakan uji korelasi Rank Spearman.

Hasil : Sebanyak (28,4\%) subjek mengalami osteopenia. Nilai z-score IMT (1,4\%) subjek kategori sangat kurus, $(13,5 \%)$ subjek kategori kurus, (6,8\%) subjek kategori kelebihan berat badan, (2,7\%) kategori kegemukan. Pengukuran persen lemak tubuh (28,4\%) subjek tergolong underfat, (9,5\%) subjek tergolong obesitas. Sebagian besar subjek kurang dalam melakukan olahraga yang meningkatkan kepadatan tulang, (16,2\%) awal usia menstruasi tergolong tidak normal. Asupan kalsium tergolong kurang (93,2) dan (40,5\%) asupan fosfor tergolong lebih. Sebanyak $(28,4)$ subyek mempunyai kepadatan tulang yang rendah. Indeks massa tubuh yang berlebih berhubungan dengan menurunnya kepadatan tulang pada remaja putri( $r=-0,231$ p=0,047).Faktor lain seperti persen lemak tubuh( $r=-0,124 p=0,293)$, kebiasaan olahraga( $r=-0,124 p=0,293)$, usia awal menstruasi $(r=-0,052$ $p=0,660)$, asupan kalsium ( $r=0,089 p=0,452)$ dan fosfor $(r=0,087 p=0.463)$ tidak menunjukkan hubungan signifikan dengan kepadatan tulang.
\end{abstract}

Kesimpulan : Ada hubungan antara indeks massa tubuh dengan kepadatan tulang.

${ }^{*}$ Penulis Penanggungjawab 
Kata Kunci : remaja putri; kepadatan tulang; indeks massa tubuh; persen lemak tubuh; kebiasaan olahraga; usia awal menstruasi; asupan kalsium dan fosfor

\section{PENDAHULUAN}

Masalah gizi pada remaja perlu mendapat perhatian khusus karena pengaruhnya yang besar terhadap pertumbuhan dan perkembangan tubuh serta dampaknya pada masalah gizi saat dewasa. Remaja merupakan masa dimana seseorang mengalami kecepatan pertumbuhan dan perkembangan untuk mencapai kematangan mental,emosional,sosial dan fisik. ${ }^{1}$ Periode ini terjadi growth spurt yaitu puncak pertumbuhan tinggi badan (peak high velocity) dan berat badan (peak weight velocity). Selain itu pada masa remaja terdapat pertumbuhan masa tulang (peak bone mass/PBM) yang menyebabkan kebutuhan gizi pada masa ini sangat tinggi bahkan lebih tinggi daripada fase kehidupan lainnya. ${ }^{2,3}$

Namun kenyataannya, baik dinegara maju maupun di negara berkembang asupan kalsium pada remaja masih sangat kurang. Sebagian remaja tidak memperoleh kalsium sebanyak yang dianjurkan oleh RDA $18 \%,{ }^{4}$ dan berdasarkan studi yang dilakukan di Cina menunjukkan bahwa asupan kalsium rata-rata pada remaja putri hanya $21 \%$. $^{2}$ Studi di India dan Bangladesh menunjukkan semua remaja putri yang ada di negara tersebut memiliki tingkat konsumsi kalsium yang lebih rendah dari RDA sehingga mengalami defisiensi kalsium. ${ }^{5}$ Selain itu, berdasarkan penelitian di Nigeria pada remaja putri menunjukkan bahwa asupan kalsium kurang dari $40 \%,{ }^{6}$ serta beberapa penelitan yang dilakukan di Indonesia menunjukkan asupan kalsium pada remaja putri berkisar antara $51,7-55,9 \% .^{2}$

Penelitian di Indonesia, pada remaja di Bogor menunjukkan bahwa asupan kalsium yang bersasal dari susu dan olahannya ditambah suplemen kalsium pada remaja masih kurang dari angka kecukupan gizi yang dianjurkan yaitu sebesar $526,9 \mathrm{mg} / \mathrm{hr}$ atau 52,7\% AKG.Sementra itu, studi konsumsi kalsium lainnya di Kota Bandung menunujukkan hasil yang tidak jauh berbeda,dengan telah memperhitungkan asupan suplemen kalsium sebesar $55,9 \%{ }^{.7}$ Asupan kalsium yang kurang pada remaja putri merupakan masalah yang potensial karena akan menyebabkan berkurangnya cadangan kalsium dalam tulang serta kekurangan kalsium selagi muda merupakan penyebab osteoporosis di usia lanjut dan keadaan ini tidak dapat diperbaiki dengan meningkatkan konsumsi kalsium ketika tanda penyakit ini tampak. $^{1,4}$
Peak bone mass sangat ditentukan oleh asupan kalsium terutama saat remaja, karena selama masa remaja terjadi penumpukan kalsium untuk pembentukan tulang yang diperkirakan mencapai rata-rata 1000 samapai $1500 \mathrm{mg} / \mathrm{hr}$. Apabila pada masa ini kalsium yang dikonsumsi kurang dan berlansung dalam waktu yang lama, PBM tidak dapat terbentuk secara optimal. Asupan kalsium yang rendah pada masa remaja berhubungan dengan penurunan isi dan densitas mineral tulang panggul sebasar 3 persen. Oleh sebab itu remaja akan beresiko terkena osteoporosis yaitu penyakit yang melumpuhkan tulang, ditandai dengan massa tulang yang rendah dan peningkatan kerapuhan tulang., ${ }^{2,8,9}$

Mekanisme pemunculan osteoporosis disebabkan oleh terganggunya keseimbangan kalsium dan fosfor didalam tubuh (rasio $\mathrm{Ca}: \mathrm{P}$ ). Minuman berkarbonat memiliki kadar asam fosfat tinggi yang menyebabkan terganggunya keseimbangan rasio $\mathrm{Ca}: \mathrm{P}$. Rasio $\mathrm{Ca}: \mathrm{P}$ normal didalam tubuh adalah $2: 1$, dalam kondisi yang cukup ideal penyerapan terhadap kalsium menjadi optimal. ${ }^{10,11}$

Menurut badan kesehatan dunia, 63\% anak di Irlandia menkonsumsi satu kaleng minuman ringan dalam setiap 24 jam serta menunjukkan bahwa perempuan di Irlandia Utara secara teratur minum minuman ringan (cola, non-cola dan diet soft drink berkarbonasi) telah mengurangi kepadatan mineral tulang. ${ }^{12}$

Penelitian di Rotterdam pada 500 anak-anak dan remaja berusia 4-20 tahun menjelaskan bahwa kebiasaan olahraga mempunyai pengaruh terhadap kepadatan tulang yang dibarengi dengan asupan kalsium yang optimal selama pubertas dibanding sebelum pubertas. ${ }^{13}$

Berdasarkan penelitian yang dilakukan di Australia dari 53 remaja putri terdapat 32\% memiliki kepadatan tulang yang rendah, mereka yang memiliki kepadatan tulang yang rendah beresiko mengalami dan memiliki tingkat estrogen yang lebih rendah. ${ }^{14}$ Penelitian yang dilakukan di Semarang pada remaja menunjukkan 55\% remaja asupan kalsiumnya masih kurang dan terdapat $18,8 \%$ remaja mengalami kepadatan tulang yang rendah.

\section{METODE PENELITIAN}

Jenis penelitian ini adalah penelitian cross sectional. Ruang lingkup penelitian ini dari segi 
keilmuan merupakan penelitian gizi masyarakat. Populasi dalam penelitian ini adalah seluruh siswi SMU I Salatiga tahun 2010. Cara pengambilan sampel menggunakan Proportionate Stratified Random Sampling. Besar sampel pada penelitian dihitung menggunakan rumus estimasi proporsi dengan koreksi sampel drop out sebesar $\pm 10 \%$. Berdasarkan perhitungan besar sampel tersebut maka jumlah sampel minimal sebanyak 63 orang. Kriteria inklusi sampel adalah tidak sedang sakit, tidak sedang menjalankan diet khusus, bukan vegetarian, tidak punya riwayat fraktur.

Data primer yang dikumpulkan yaitu identitas diri, usia, berat badan, tinggi badan, awal usia menstruasi, kebiasaan olahraga yang meningkatkan kepadatan tulang, konsumsi minuman berkarbonat, dan asupan makanan. Berat badan diukur dengan timbangan digital yang memiliki ketelitian 0,1 kilogram. Tinggi badan diukur dengan microtoise yang memiliki ketelitian 0,1 centimeter. Persen lemak tubuh diukur dengan menggunakan timbangan digital BIA (Bio Impedance Analyzer). Kebiasaan olahraga diperoleh pencatatan kebiasaan olahraga selama sehari dengan menggunakan kuesioner kebiasaan olahraga yg meningkatkan kepadatan tulang. Asupan makanan ditelusuri secara restrospektif dengan menggunakan recall 24 jam selama 3 hari dan food frequency.

Variabel bebas dalam penelitian ini adalah asupan kalsium dan fosfor, kebiasaan olahraga yang meningkatkan kepadatan tulang, awal usia menstruasi, indeks massa tubuh, persen lemak tubuh. Variabel terikat dalam penelitian ini adalah kepadatan tulang. Analisis data dilakukan dengan menggunakan program komputer Statistical Package for the Social Science (SPSS) 17.0 for windows dengan derajat kemaknaan 95\% ( $\alpha=$ 0,05). Uji kenormalan menggunakan uji Kolmogorov-Smirnov.

Analisis univariat dilakukan terhadap data usia responden, indeks massa tubuh (IMT), persen lemak tubuh, kebiasaan olahraga, usia awal menstruasi, asupan kalsium dan fosfor, kepadatan tulang. Indeks massa tubuh (IMT) diinterpretasikan dengan menggunakan nilai $z$-score. Nilai $z$-score dikategorikan menjadi 5, yaitu > +2SD tergolong kategori kegemukan (obesity), >+1SD tergolong kategori kelebihan berat badan (overweight), -1SD sampai +1 SD tergolong katergori normal, <-2SD tergolong kategori kurus (thinness), dan $<-3 \mathrm{SD}$ tergolong kategori sangat kurus (severe thinnes). ${ }^{15}$ Persen lemak tubuh dikategorikan menjadi 4 yaitu underfat bila persentil $\leq 2$, normal bila persentil lebih dari 2 sampai dengan 85 , overfat bila persentil lebih dari 85 sampai dengan 95, dan obesitas bila persentil $>95 .{ }^{16}$ Kebiasaan olahraga dikategorikan menjadi 2 yaitu kurang jika besar skor aktivitas < 1800, dan baik jika besar skor aktivitas $\geq 1800 .{ }^{17}$ Usia menstruasi dikategorikan menjadi 2, yaitu normal apabila mendapat haid pertama pada usia $\geq 11 \mathrm{~s} / \mathrm{d} \leq 15$ tahun dan tidak normal bila mendapat haid pertama pada usia $>15$ tahun. ${ }^{18}$ Asupan kalsiumdan fosfor dikategorikan menjadi 2 berdasarkan persentase terhadap AKG individu, yaitu asupan kurang jika $<80 \%$, sesuai jika asupan $100 \%$, dan asupan lebih jika $>100 \% .{ }^{8}$ Kepadatan dikategorikan menjadi 3, yaitu normal bila $\mathrm{T}$ skor lebih dari-1 SD, osteopenia bila $\mathrm{T}$ skor kurang dari -1 sampai -2,5 SD dan osteoporosis bila T skor kurang dari $-2,5 \mathrm{SD} .{ }^{19}$

Analisis hubungan antara variabel bebas dengan variabel terikat terlebih dahulu dilakukan uji kenormalan data dengan Kolmogorov Smirnov. Variabel dengan distribusi normal adalah indeks massa tubuh dan persen lemak tubuh, sedangkan variabel lain yaitu: kepadatan tulang, Kebiasaan olahraga, usia awal mestruasi, asupan kalsium, dan asupan fosfor tidak berdistribusi normal. Analisis bivariat dilakukan dengan menggunakan uji korelasi rank Spearman. Analisis bivariat dilakukan untuk mengetahui adanya hubungan antara variabel terikat, yaitu kepadatan tulang remaja dengan variabel bebas, yaitu indeks massa tubuh, persen lemak tubuh, kebiasaan olahraga, usia awal menstruasi, asupan kalsium, dan asupan fosfor.

\section{HASIL PENELITIAN}

Penelitian dilakukan di SMU 1 Salatiga pada bulan Februari sampai dengan Maret 2011. Pengambilan sampel dilakukan secara acak sehingga diperoleh sampel sebanyak 84 siswa. Sebanyak 10 sampel drop out karena tidak hadir saat pengambilan data asupan makanan sehingga jumlah subjek penelitian ini menjadi 74 siswi.

\section{A. Analisis Univariat}

\section{Karakteristik subjek}

\section{a. Usia}

Usia subjek dalam penelitian berkisar antara 14-18 tahun dengan frekuensi terbesar yaitu usia 16 tahun sebanyak 44 subjek (50\%). Berikut adalah distribusi frekuensi menurut usia subjek. 
Tabel 1. Distribusi frekuensi subjek menurut usia

\begin{tabular}{lcc}
\hline Usia & Frekuensi & Persen $(\%)$ \\
\hline 14 tahun & 1 & 1,4 \\
15 tahun & 16 & 21,6 \\
16 tahun & 44 & 59,5 \\
17 tahun & 12 & 16,2 \\
18 tahun & 1 & 1,4 \\
\hline Total & 74 & 100 \\
\hline
\end{tabular}

\section{b. IMT}

Kategori status gizi diperoleh berdasarkan nilai z-score BMI menurut usia 5-19 tahun. Hasil pengukuran antropometri berupa indeks massa tubuh yang diinterprertasikan dengan z-score menunjukkan bahwa sebanyak $10(13,5 \%)$ subjek tergolong kurus dan 5 (6,8\%) subjek tergolong kelebihan berat badan.

Berikut adalah distribusi frekuensi subjek menurut nilai $z$-score.

Tabel 2. Distribusi frekuensi subjek menurut nilai z-score

\begin{tabular}{|c|c|c|c|}
\hline Status gizi & & Frekuensi & Persen $(\%)$ \\
\hline Sangat kurus & & 1 & 1,4 \\
\hline Kurus & & 10 & 13,5 \\
\hline Normal & & 56 & 75,7 \\
\hline $\begin{array}{l}\text { Kelebihan } \\
\text { badan }\end{array}$ & berat & 5 & 6,8 \\
\hline Kegemukan & & 2 & 2,7 \\
\hline Total & & 80 & 100 \\
\hline
\end{tabular}

\section{c. Persen lemak tubuh}

Berdsasarkan hasil pengukuran persen lemak tubuh diketahui bahwa $21(28,4 \%)$ subjek memiliki persen lemak tubuh dengan kategori underfat, namun 7 (9,5\%) subjek diantaranya tergolong obesitas.Berikut adalah distribusi frekuensi subjek menurut persen lemak tubuh.

Tabel 3. Distribusi frekuensi subjek menurut persen lemak tubuh

\begin{tabular}{lcc}
\hline Persen lemak tubuh & Frekuensi & Persen $(\%)$ \\
\hline Underfat & 21 & 28,4 \\
Normal & 33 & 44,6 \\
Overfat & 13 & 17,6 \\
Obesitas & 7 & 9,5 \\
\hline
\end{tabular}

\section{Kepadatan tulang}

Kejadian Osteoporosis belum ditemukan. Namun ditemukan kejadian osteopenia. Sebanyak18 (28,6\%) subjek tergolong osteopenia. Berikut adalah distribusi frekuensi subjek menurut kepadatan tulang.

Tabel 4. Distribusi frekuensi subjek menurut kepadatan tulang

\begin{tabular}{lcc}
\hline Kepadatan tulang & Frekuensi & Persen $(\%)$ \\
\hline Normal & 53 & 71,6 \\
Osteopenia & 21 & 28,4 \\
\hline
\end{tabular}


Kejadian Osteopenia dapat kurang maupun status gizi lebih. terjadi pada subjek dengan status gizi

a. Tabel 5. Kategori kepadatan tulang berdasarkan status gizi

\begin{tabular}{llll}
\hline \multirow{2}{*}{ Kategori Z-core } & Normal & $\begin{array}{c}\text { Kategori kepadatan tulang } \\
\text { osteopenia }\end{array}$ & Total \\
\hline Sangat kurus & 0 & 1 & 1 \\
Kurus & 8 & 2 & 10 \\
Normal & 40 & 16 & 56 \\
Overweight & 3 & 2 & 5 \\
Obesity & 2 & 0 & 2 \\
Total & & & \\
\hline
\end{tabular}

Kejadian Osteopenia ditemukan pada 6 subjek yang underfat, 4 subjek overfat serta 2 subjek yg obesity.

b. Tabel 6 . Kategori kepadatan tulang berdasarkan persen lemak tubuh

\begin{tabular}{llll}
\hline & \multicolumn{2}{c}{ Kategori kepadatan tulang } \\
\hline kategori PLT & Normal & osteopenia & Total \\
Underfat & 15 & 6 & 1 \\
Normal & 24 & 9 & 10 \\
Overfat & 9 & 4 & 56 \\
Obesity & 5 & 2 & 5 \\
Total & 53 & 21 & 74 \\
\hline
\end{tabular}

\section{Kebiasaan olahraga}

Kebiasaan olahraga didapatkan dari kuesioner kebiasaan olahraga yang meningkatkan densitas tulang (naik turun tangga, senam, yoga, dll). Berdasarkan kuesioner kebiasaan olahraga ditemukan sebanyak $63 \quad(85,1 \%)$ subjek memiliki kebiasasan olahraga yang tergolong kurang untuk menigkatkan densitas tulang.

Distribusi frekuensi subjek menurut kebiasaan olahraga dapat dilihat pada tabel 7.

Tabel 7. Distribusi frekuensi subjek menurut Kebiasaan olahraga

\begin{tabular}{lcc}
\hline Kebiasaan olahraga & Frekuensi & Persen (\%) \\
\hline Kurang & 63 & 85,1 \\
Baik & 11 & 14,9 \\
\hline
\end{tabular}

Kejadian Osteopenia ditemukan pada 20 subjek yang kurang dalam melakukan kebiasaan olahraga yang dapat meningkatkan kepadatan tulang. 
c. Tabel 8 Kategori kpadatan tulang berdasarkan kebiasaan olahraga

\begin{tabular}{llll}
\hline & \multicolumn{3}{c}{ Kategori kepadatan tulang } \\
\hline Kategori kebiasaan olahraga & normal & Osteopenia & Total \\
Kurang & 43 & 20 & 63 \\
Baik & 10 & 1 & 11 \\
Total & 53 & 21 & 74 \\
\hline
\end{tabular}

4. Usia awal mestruasi

Sebanyak $12 \quad(16,2 \%)$ subjek mendapat menstruasi pertama kali pada usia lebih dari 15 tahun sehingga tergolong tidak normal. Deskripsi frekuensi subjek menurut usia awal menstruasi tersaji pada tabel 9.

Tabel 9. Distribusi frekuensi subjek menurut usia awal menstruasi

\begin{tabular}{lcc}
\hline Usia awal mestruasi & Frekuensi & Persen $(\%)$ \\
\hline Tidak normal & 12 & 16,2 \\
Normal & 62 & 83,8 \\
\hline
\end{tabular}

Kejadian Osteopenia ditemukan pada 8 subjek yang mendapat menstruasi pada usia yg tidak normal.

d. Tabel 10. Kategori kepadatan tulang berdasarkan usia awal menstruasi

\begin{tabular}{llll}
\hline & \multicolumn{3}{c}{ Kategori kepadatan tulang } \\
\hline kategori usia awal menstruasi & normal & Osteopenia & Total \\
Tidak normal & 4 & 8 & 12 \\
Normal & 49 & 13 & 62 \\
Total & 53 & 21 & 74 \\
\hline
\end{tabular}

\section{Asupan kalsium dan fosfor}

Asupan kalsium dan fosfor menunjukkan data yang berlawanan dimana asupan kalsium sebanyak 69 $(93,2 \%)$ subjek tergolong kurang sedangkan asupan fosfor sebanyak 30 (40,5\%) subjek tergolong lebih. Tabel 11 menunjukkan distribusi frekuensi subjek menurut asupan kalsium dan fosfor.

Tabel 11.Distribusi frekuensi subjek menurut asupan kalsium dan fosfor

\begin{tabular}{clcc}
\hline Kategori asupan mineral & Kategori & Frekuensi & Persen (\%) \\
\hline Kategori asupan kalsium & Kurang & 69 & 93,2 \\
& Sesuai & 0 & 0 \\
& Lebih & 5 & 6,8 \\
Kategori asupan fosfor & Kurang & 44 & 59,5 \\
& Sesuai & 0 & 0 \\
& Lebih & 30 & 40,5 \\
\hline
\end{tabular}

Kejadian Osteopenia ditemukan pada 20 subjek yang kurang dalam mengonkonsumsi makanan sumber kalsium. 
e. Tabel 12. Kategori kepadatan tulang berdasarkan asupan kalsium dan fosfor

\begin{tabular}{llccc}
\hline & & \multicolumn{3}{c}{ Kategori kepadatan tulang } \\
\hline Kategori asupan mineral & Kategori & Normal & Osteopenia & Total \\
\hline Kategori asupan kalsium & Kurang & 50 & 20 & 70 \\
& Sesuai & 3 & 1 & 4 \\
Kategori asupan fosfor & Kurang & 1 & 0 & 1 \\
& Sesuai & 52 & 21 & 73
\end{tabular}

B. Analisis Bivariat

Hubungan Beberapa Variabel (Indeks Massa Tubuh,Persen Lemak Tubuh, Kebiasaan Olahraga, Usia Awal Menstruasi, Asupan Kalsium, dan Asupan Fosfor) dengan Kepadatan Tulang

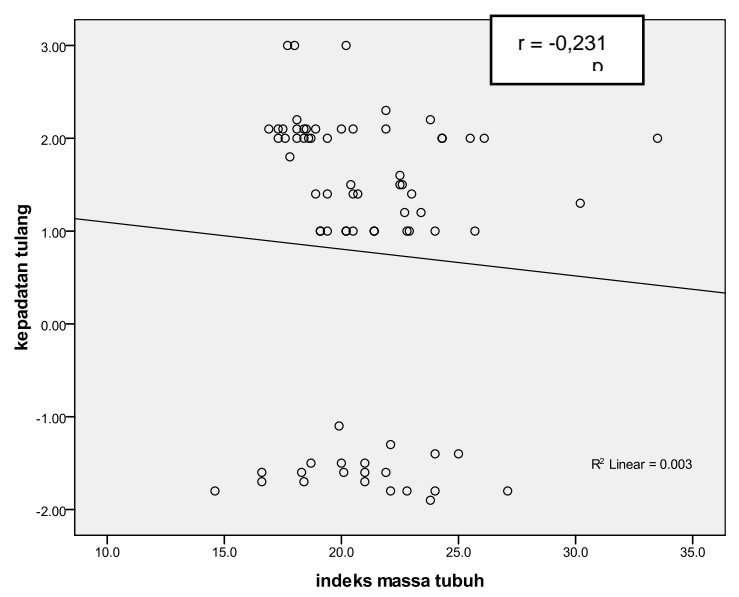

Gambar 1. Hubungan antara indeks massa tubuh dengan kepadatan tulang

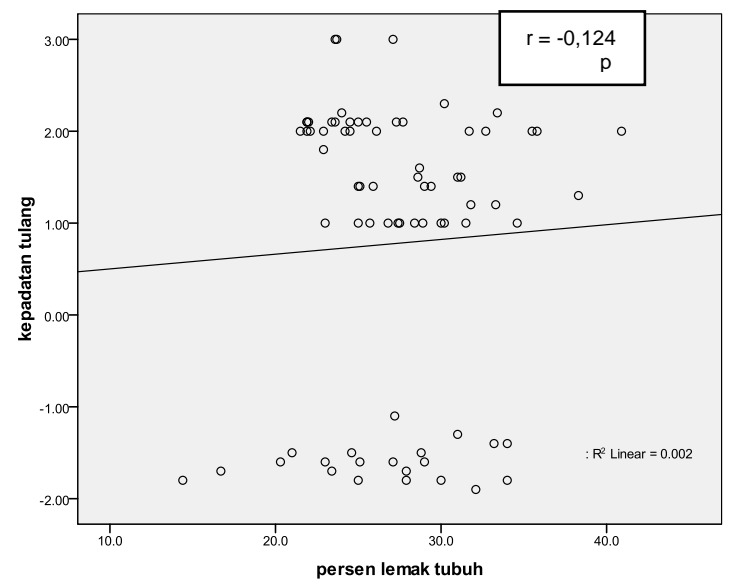

Gambar 2. Hubungan antara persen lemak tubuh dengan kepadatan tulang
Hasil uji bivariat menunjukkan adanya hubungan antara indeks massa tubuh dengan kepadatan tulang. Hasil uji bivariat menunjukkan tidak ada hubungan antara persen lemak tubuh, kebiasaan olahraga, usia awal menstruasi, asupan kalsium, dan asupan fosfor dengan kepadatan tulang.

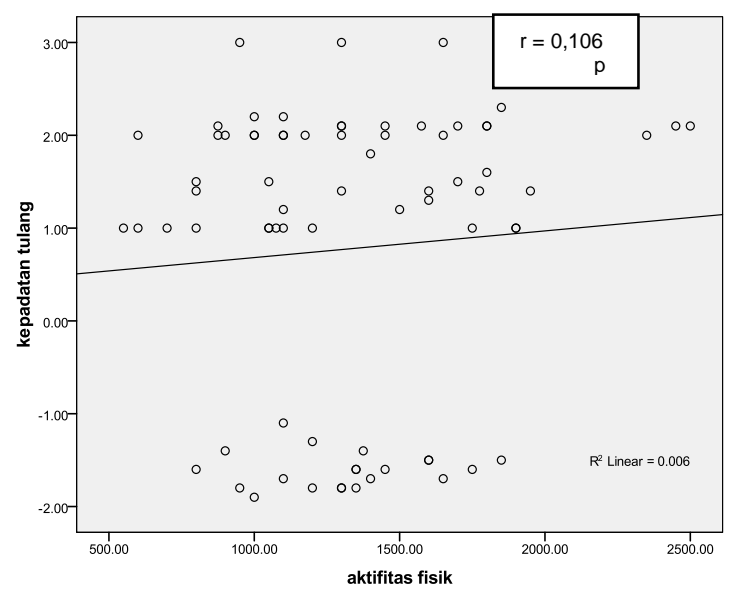

Gambar 3. Hubungan antara kebiasaan olahraga dengan kepadatan tulang

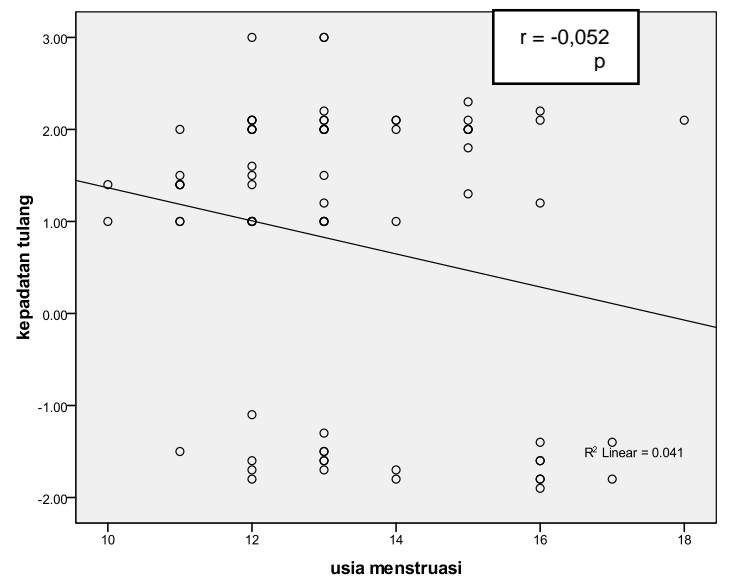

Gambar 3. Hubungan antara usia awal menstruasi dengan kepadatan tulang 


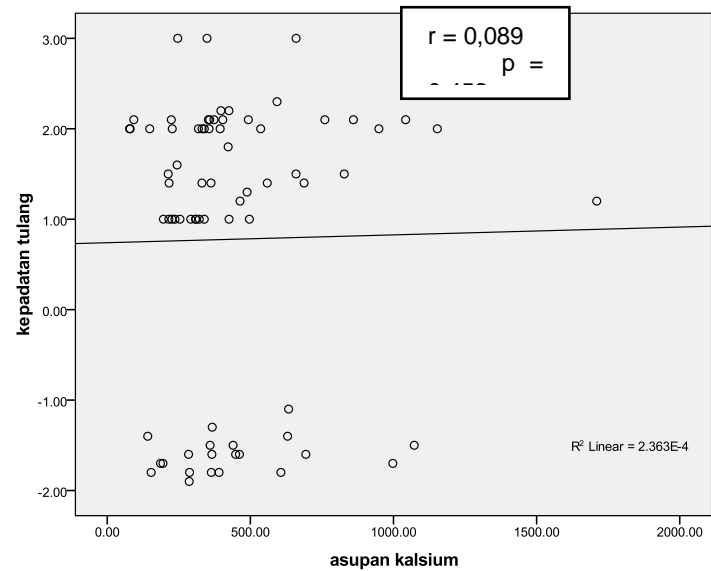

Gambar 5. Hubungan antara asupan kalsium dengan kepadatan tulang

\section{PEMBAHASAN}

\section{Karakteristik Subjek}

Subjek penelitian adalah remaja putri yang berusia $14-18$ tahun. Pembentukan tulang paling cepat terjadi pada usia pubertas. Kecepatan pertumbuhan pada masa remaja jauh lebih besar dibandingkan dengan pertumbuhan pada masa anak-anak. Pada masa ini terdapat percepatan pertumbuhan tulang (growth spurt) yang menyebabkan kebutuhan gizi pada masa ini sangat tinggi, terutama kalsium, daripada fase kehidupan lainnya. ${ }^{4}$ Lebih dari $20 \%$ pertumbuhan tinggi badan dan sekitar 50\% massa tulang dewasa dicapai pada masa remaja. ${ }^{15}$ Sementara itu gaya hidup remaja seperi kurangnya aktivitas fisik dan asupan mineral (kalsium dan fosfor) yang kurang seimbang tidak mendukung pertumbuhan tulang mereka. Kejadian osteoporosis lebih besar pada perempuan dibanding dengan laki-laki. Perempuan memiliki risiko terkena osteoporosis lebih besar dari pada laki-laki karena lebih sedikitnya massa tulang yang dimiliki dan lebih cepatnya mengalami kehilangan massa tulang. ${ }^{20,21}$

\section{Kepadatan Tulang}

Pada penelitian ini belum ditemukan kejadian osteoporosis. Namun ditemukan sebanyak 21 $(28,4 \%)$ subjek mengalami osteopenia. Osteopenia merupakan tanda awal dari osteoporosis. Pada pemeriksaan densitas tulang ditemukan pengeroposan tulang dalam derajat yang lebih ringan.

Osteopenia apabila tidak ditangani dengan baik dapat berisiko mengalami osteoporosis atau patah tulang. ${ }^{22}$ Osteopenia pada remaja dapat dipengaruhi oleh beberapa faktor seperti gaya hidup kurang aktif serta asupan zat gizi pembentuk

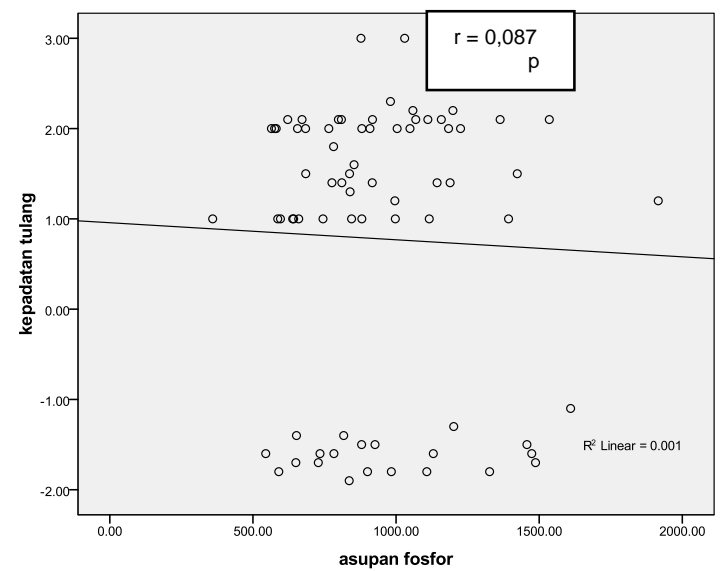

\section{Gambar 6. Hubungan antara asupan fosfor dengan kepadatan tulan}

tulang yang rendah. Sebuah studi menunjukkan bahwa asupan makanan pada masa remaja dan sedentary lifestyle dapat mempengaruhi pencapaian puncak massa tulang. Asupan kalsium merupakan faktor yang paling kuat berhubungan dengan massa tulang di masa pubertas. Gaya hidup sedentary memiliki hubungan negatif dengan massa tulang dewasa. ${ }^{23}$

Indeks Massa Tubuh dan Persen Lemak Tubuh

Indeks massa tubuh (IMT) merupakan kombinasi parameter berat badan dan tinggi badan yang digunakan untuk menggambarkan status gizi. Indeks massa tubuh pada remaja dapat diinterpretasikan dengan menggunakan nilai zscore. Pada penelitian ini diperoleh1 $(1,4 \%)$ subjek dengan kategori sangat kurus, $10(13,5 \%)$ subjek dengan kategori kurus, 5 (6,8\%) subjek dengan kategori kelebihan berat badan, dan $2(2,7 \%)$ subjek dengan kategori kegemukan. Berdasarkan data tersebut dapat dilihat bahwa masalah gizi ganda terjadi pada siswa SMU Negeri 1 Salatiga.

Persen lemak tubuh merupakan persentase massa lemak dari total berat badan. Persen lemak tubuh sering digunakan untuk mengevaluasi komposisi tubuh seseorang ataupun penentuan status gizi. ${ }^{19}$ Berdasarkan pengukuran persen lemak tubuh diketahui sebanyak $21 \quad(28,4 \%)$ subjek tergolong underfat dan 7 (9,5\%) subjek tergolong obesitas.

Hasil uji bivariat menunjukkan adanya hubungan bermakna antara indeks massa tubuh dengan kepadatan tulang $(\mathrm{r}=-0,231 \mathrm{p}=0,047)$. Pada hasil pengukuran indeks massa tubuh dari penelitian ini diperoleh $1(4,8 \%)$ subjek dengan kategori sangat kurus dan $2(9,5 \%)$ subjek dengan kategori kurus mengalami osteopenia. Selain itu, diperoleh 2 (9,5\%) subjek dengan kategori 
kelebihan berat badan mengalami osteopenia. Penelitian terdahulu menyatakan bahwa rendahnya indeks massa tubuh berhubungan dengan rendahnya pencapaian puncak massa tulang dan tingginya kehilangan massa tulang. Wanita bertubuh ramping/kurus dan yang memiliki tulang kecil memiliki resiko osteoporosis lebih besar daripada yang memiliki tubuh overweight(gemuk) dan memiliki tulang besar. Hal ini dapat disebabkan berkurangnya produksi peripheral oleh jaringan lemak pada wanita kurus dan rendahnya beban mekanis pada rangka. ${ }^{20,24}$

Akan tetapi tidak didapatkan hubungan bermakna antara persen lemak tubuh dengan kepadatan tulang $(\mathrm{r}=-0,124 \mathrm{p}=0,293)$. Sedangkan berdasarkan persen lemak tubuh diperoleh 6 $(28,6 \%)$ subjek dengan kategori underfat mengalami osteopenia serta $4(19 \%)$ subjek dengan kategori overfat dan 2 (9,5\%) subjek dengan kategori obesity mengalami osteopenia.

Hal ini dapat dipengaruhi oleh jumlah sampel yang sedikit dan karakteristik subjek penelitian berdasarkan persen lemak tubuh kuranng heterogen.

Akan tetapi penelitian terbaru menyatakan bahwa wanita dengan obesitas memiliki risiko osteoporosis lebih tinggi. Peningkatan lemak tubuh akan menekan pembetukan kolagen baru. Wanita dengan obesitas memiliki kecepatan pembentukan tulang yang lebih rendah. ${ }^{25}$ Penelitian pada remaja putri dengan obesitas menyatakan bahwa lemak viseral memiliki efek negatif terhadap kepadatan tulang. Remaja putri obese dengan lemak viseral yang lebih tinggi mempunyai kepadatan tulang yang lebih rendah. ${ }^{26,27}$ Penelitan lain yang dilakukan pada remaja dan dewasa muda juga menunjukkan hasil bahwa massa lemak tidak memberikan keuntungan terhadap struktur tulang. Hal ini dikarenakan kekuatan tulang utamanya ditentukan oleh beban dinamis dari tekanan otot, dan bukan beban statis seperti massa lemak. ${ }^{28}$

Studi lain juga menunjukkan data kejadian gangguan ortopedi yang lebih banyak dialami oleh anak dan remaja dengan overweight dibandingkan dengan anak dan remaja yang tidak overweight. Anak dengan berat badan berlebih dapat mengalami kesulitan bergerak dan gangguan keseimbangan yang dapat berisiko terjadi cidera jatuh saat melakukan aktivitas sehari-hari. Sementara itu peningkatan mineral tulang yang terjadi pada anak yang kelebihan berat badan tidak dapat menyesuaikan dengan tekanan yang terjadi saat jatuh. Dengan demikian risiko terjadi patah tulang juga lebih besar terjadi. ${ }^{29}$

\section{Kebiasaan olahraga}

Kebiasaan olahraga dari 54 (85,7\%) subjek penelitian ini tergolong kurang. Hasil penelitian ini menunjukkan hasil bahwa tidak ada hubungan yang bermakna antara kebiasaan olahraga dengan kepadatan tulang. Hal ini dapat dipengaruhi oleh karakteristik subjek penelitian. Subjek penelitian ini merupakan siswa SMU dengan tingkat kebiasaan olahraga yang termasuk ringan. Sebagian besar subjek jarang melakukan olahraga selain di sekolah. Selain karakteristik subjek, jenis olahraga yang dilakukan oleh sebagian besar subjek merupakan jenis olahraga yang tidak meningkatkan kepadatan tulang. Beberapa jenis olahraga yang sering dilakukan antara lain basket, volly, senam, dan renang.

Kebiasaan olahraga dibutuhkan untuk mempertahankan kesehatan tulang. ${ }^{30}$ Kebiasaan olahraga mempengaruhi tulang secara langsung maupun tidak langsung. Pengaruh langsung terhadap tulang melalui mekanisme pembebanan pada tulang sedangkan secara tidak langsung melalui faktor hormonal.Kebiasaan olahraga meningkatkan massa tulang dengan meningkatkan massa otot yang memberikan pembebanan pada tulang. Densitas tulang meningkat sebagai respon dari pembebanan fisik dan mekanis pada tulang. Pembebanan dari kebiasaan olahraga dibutuhkan tulang agar pembentukan tulang dapat mengimbangi kehilangan tulang yang terjadi. ${ }^{20,21}$

Data menunjukkan bahwa kebiasaan olahraga yang dimulai sejak masa muda memberikan kontribusi tinggi terhadap pencapaian puncak massa tulang. Olahraga seperti latihan ketahanan dan menahan berat dapat memberikan keuntungan karena dapat membantu pembentukan tulang dan menjaga massa tulang. ${ }^{31}$ Sebuah studi pada anak-anak menunjukkan bahwa kebiasaan olahraga harian yang dinamis setidaknya selama 25 menit dapat meningkatkan kekuatan tulang. ${ }^{32}$ Akan tetapi, sebuah studi lain menunjukkan meskipun aktivitas dapat memberikan keuntungan untuk kesehatan tulang, ada batas dimana patah tulang meningkat dengan aktivitas tinggi. ${ }^{33}$

Disarankan kebiasaan olahraga dan olahraga dengan intensitas pembebanan tingkat menengah hingga tinggi, yaitu : kebiasaan olahraga 3-5 kali per minggu dengan 2-3 kali per minggu olahraga ketahanan (resistance exercise), ataupun kombinasi keduanya selama 30-60 menit per minggu. ${ }^{21,34}$

\section{Usia Awal Mestruasi}


Pada penelitian ini tidak terdapat hubungan yang bermakna antara usia awal menstruasi dengan kepadatan tulang. Terlambatnya pubertas pada pria dan wanita dan amenorrhea (periode menstruasi yang panjang) pada wanita berhubungan dengan meningkatnya resiko osteoporosis. ${ }^{14,20,21}$ Penelitian pada 295 remaja putri di Roterdam memperlihatkan remaja putri yang telah mengalami menarche memiliki massa tulang yang lebih tinggi daripada yang belum mengalami menarche. ${ }^{35}$ Penelitian lain menunjukkan bahwa keterlambatan usia awal menstruasi dihubungkan dengan risiko 2 kali lebih besar terhadap rendahnya kepadatan tulang di bagian ekstremitas bawah. $^{36}$

\section{Asupan Kalsium dan Fosfor}

Persentase asupan kalsium diperoleh 66 $(89,2 \%)$ subjek tergolong kurang dari kebutuhan yang dianjurkan yaitu $1000 \mathrm{mg}$. Asupan kalsium subjek perhari kurang dari $50 \%$ AKG. Asupan kalsium subjek penelitian yang tergolong kurang disebabkan karena rendahnya asupan makanan sumber kalsium. Sumber kalsium terutama terdapat pada susu dan hasil olahannya (susu, keju, yogurt), ikan yang dimakan dengan tulangnya (teri, ikan kalengan seperti sarden), brokoli, dan makanan yang diperkaya dengan kalsium. ${ }^{34}$ Faktor yang berkontribusi pada rendahnya asupan $\mathrm{Ca}$ adalah pembatasan konsumsi susu dan hasil olahannya, rendahnya konsumsi buah dan sayur secara umum, tingginya konsumsi minuman rendah kalsium seperti soda. ${ }^{30}$

Berdasarkan data asupan makanan yang diperoleh diketahui bahwa asupan kalsium subjek penelitian lebih sering berasal dari makanan nabati seperti tempe dan tahu. Makanan sumber kalsium lain yang biasa dikonsumsi subjek antara lain sosis, bakso, telur dan daging ayam. Susu jarang dikonsumsi oleh subjek penelitian ini. Frekuensi minum susu subjek hanya 3 kali seminggu dari sebagian kecil subjek.

Subjek penelitian lebih sering mengkonsumsi teh, kopi, dan minuman ringan sebagai pengganti susu. Beberapa alasan subjek penelitian ini jarang minum susu antara lain takut gemuk, rasa mual setelah minum susu, harga mahal, dan kurangnya pengetahuan tentang gizi. Sebuah studi menunjukkan bahwa wanita dengan konsumsi susu yang rendah selama masa anakanak dan remaja memiliki massa tulang yang rendah saat usia dewasa dan memiliki risiko lebih besar untuk terjadi patah tulang. ${ }^{37}$

Kalsium merupakan mineral yang paling banyak terdapat dalam tubuh. Kalsium sangat penting untuk memaksimalkan pembentukan puncak massa tulang (peak bone mass) pada masa anak-anak dan remaja. Intake kalsium yang tinggi sangat diperlukan pada awal kehidupan dan pada awal kehidupan dan masa pertumbuhan remaja untuk meningkatkan densitas tulang. Jumlah kalsium dalam tulang berubah menurut umur, ukuran dan komposisi tubuh.

Penyerapan kalsium sangat bervariasi tergantung umur dan kondisi tubuh. Pada waktu pertumbuhan sekitar $50-70 \%$ kalsium yang dicerna diserap. Dalam keadaan normal kalsium yang dikonsumsi dapat diabsorbsi oleh tubuh sebanyak 30-50\%, kemampuan absorpsi lebih tinggi pada masa pertumbuhan dan menurun pada proses penuaan. Kemampuan absorpsi pada laki-laki lebih tinggi daripada perempuan pada semua golongan usia. ${ }^{10,11}$

Banyak studi yang dilakukan memperlihatkan hubungan yang relatif konsisten dan bersifat positif antara asupan kalsium dan BMD. Pada penelitian ini tidak didapatkan hubungan bermakna antara asupan kalsium dengan kepadatan tulang. Hal ini dapat dipengaruhi oleh rasio asupan kalsium dengan asupan fosfor. Hasil penelitian ini menunjukkan adanya rasio yang tidak seimbang asupan kalsium dan fosfor dimana asupan fosfor lebih tinggi.

Meskipun fosfor merupakan zat gizi penting, tetapi konsumsi yang berlebih dapat merugikan tulang. Fosfor di dalam tulang berada dalam perbandingan 1:2 dengan kalsium. Rasio fosfor terhadap kalsium yang tinggi dalam makanan dapat menurunkan absorpsi kalsium karena pembentukan garam kalsium oksalat yang tidak larut air. Selain itu kombinasi asupan fosfor tinggi dan asupan kalsium rendah akan meningkatkan konsentrasi hormon paratiroid dan dapat menurunkan kepadatan tulang. ${ }^{20}$ Selain karena rasio asupan kalsium dan fosfor, absorpsi kasium juga dapat dipengaruhi oleh fitat, oksalat, dan mineral lain seperti seng dan magnesium. ${ }^{11}$ Sebuah studi menunjukkan bahwa tingginya konsumsi protein, kafein, phosfor, dan garam dapat berakibat negatif terhadap keseimbangan kalsium. Akan tetapi efek ini tidaklah penting pada individu dengan asupan kalsium yang cukup. ${ }^{30}$

Persentase asupan fosfor dari 23 subjek penelitian ini $(31,1 \%)$ tergolong kurang dari $80 \%$ AKG. Sebanyak 30 subjek $(40,5 \%)$ memilki persentase asupan fosfor lebih dari 100\% AKG. Rerata asupan fosfor subjek perhari adalah 947,36 $\pm 301,17$. Hasil uji bivariat tidak 
menunjukkan adanya hubungan yang bermakna antara asupan fosfor dengan kepadatan tulang.

Fosfor adalah mineral terbanyak kedua setelah kalsium dalam tubuh, yaitu $1 \%$ berat badan. Kurang lebih $85 \%$ fosfor didalam tubuh bersama-sama dengan kalsium berada dalam rangka dan gigi dalam bentuk kalsium fosfat yaitu bagian dari kristal hidroksiapatit yang tidak dapat larut yang memberi kekuatan dan kekakuan pada tulang yang berperan sebagai struktural. Kegunaan utama fosfor adalah mendukung pertumbuhan dan penggantian tulang yang hilang. ${ }^{7,10,11}$

Asupan fosfor yang tinggi dari subjek penelitian ini berasal dari minuman berkabonat. Minuman berkarbonat dikonsumsi oleh subjek penelitian ini 3-4 kali dalam seminggu. Penelitian yang dilakukan tentang minuman cola menyatakan bahwa konsumsi cola diasosiasikan dengan kepadatan tulang yang rendah. Pada penelitian tersebut ditemukan bahwa rasio kalsium terhadap fosfor pada subjek yang mengkonsumsi cola setiap hari lebih rendah. $^{38}$ Penelitian lain tentang minuman ringan juga menunjukkan bahwa konsumsi minuman ringan, baik yang berkafein dan berkarbonat maupun yang tidak berkafein, dalam jangka panjang memiliki efek negatif terhadap kandungan mineral tulang. ${ }^{39}$

\section{SIMPULAN}

Kepadatan tulang yang rendah dialami pada subjek dengan kekurangan atau kelebihan berat badan dan persen lemak dalam tubuh, aktivitas olahraga yang rendah serta subjek dengan asupan kalsium dan fosfor yang tidak seimbang.

\section{SARAN}

Peningkatan kepadatan tulang pada remaja dapat dilakukan dengan cara meningkatakan frekuensi olahraga yang dapat menambah kepadatan tulang, mengkonsumsi bahan makanan sumber kalsium dan fosfor secara seimbang untuk mempertahankan berat bdan yang optimal.

\section{DAFTAR PUSTAKA}

1. Sandra Fikawati, Ahmad Syafiq. Konsumsi Kalsium Pada Remaja Dalam Gizi dan Kesehatan Masyarakat. Jakarta:Raja Grafindo Persada.2007. Hal:169-94

2. Eddy Fadillah.Gangguan Pertumbuhan Linier Pada Remaja Dalam Tumbuh Kembang Remaja DanPermasalahan.Jakarta:CV.Sagungseto.2007.Hal 59-60.

3. Tarwoto, Ratna Aryani, Ani Nuraeni, Bara Miradwijaya, Siti Nurbayani, Siti Aminah,Et Al.
Kesehatan Remaja Problem Dan Solusinya. Jakarta:Salemba Medika. 2010. Hal:1-15

4. Arisman. Gizi dalam Daur Kehidupan. Edisi 2.Jakarta:EGC.2009.Hal: 77-100

5. Whiting SJ,Hassanali Vatanparast, Baxter JA,Faulkner RA.,Mirwald Robert, Donald Bailey.Factors That Bone Mineral Accrual in The Adolescent Growth Spurt.American Society For Nutritionl Science.2004. p: 696-9

6. Agoreyo,Ogochukwu Blesing,Obuekw,Flossy Ifeyinwa. Public Health Implications of the Declining Calcium Intake In Female Adolescents from a Nigerian University.Journal of International Women's Studies.2002. Vol 4.p: 35-42

7. Fikawati S, Ahmad Syafid, Puri Puspasari. Faktorfaktor Yang Berhubungan dengan Asupan Kalsium pada Remaja di Kota Bandung. Jurnal Kedokteran Trisakti.Januari- Maret.2005.Vol24. No.1

8. Moesijanti S, Djoko K. Prosiding Ketahanan Pangan dan Gizi di Era Otonomi Daerah dan Globalisasi.Jakarta:Lipi.2004. Hal:376-9

9. Kalkwarf HJ,Khoury JC,Lanphear BP. Milk Intake During Childhood and Adolescence,Adult Bone Density, And Osteoporotic Fractur in US Women.American Journal of Clinical Nutrition.2003.Vol 7

10. Sunita A. Prinsip Dasar Ilmu Gizi. Jakarta:PT.Gramedia.2006. Hal 236

11. Carolyn Beradanier. Advanced Nutrition Micronutrients.New York:CRC Press. 2000. Page $163-174$

12. McGartland C. Carbonated soft drink consumption and bone mineral density in adolescence: The Northern Ireland Young Hearts Project. J Bone Miner Res. 2003. vol18: p. 1563-9.

13. Annemieke M, Maria AJ, De Ridder, Huibert AP, Eric PK, Sabine M PF, de Muinck KS.Bone Mineral Density in Children and Adolescents: Relation to Puberty, Calcium Intake, and Physical Activity.Journal of Clinical Endocrinology and Metabolism. 2007; vol .82. No.1. p: 37-62

14. Turner JM,Bulsara MK,McDermott BM,Byrne GC,Prince RL,Forbes DA. Predictor OF Low Bone Density In Young Adolescent Females With Anorexia Nervosa And Other Dieting Disorders. National Health and Medical Reserch Council Of Australia.2000. p: 246-251

15. WHO. Growth Reference 5-19 year for Adolescents.2007

16. Davison K.K, Elisabeth J, Susman and Bircrh L.L. Percent Body Fat at age Predicts Earlier Pubetal Development among Girls. Journal of The American Academy Of Pediatric. 2003:111;p. 815821

17. Soetjiningsih. Pertumbuhan Somatik Pada Remaja dalam Tumbuh Kembang Remaja dan Permasalahannya. Seto.2007.Hal 1-22 Jakarta:CV.Sagung 
18. Fatmah. Gizi kebugaran dan olahraga. Bandung. Lubuk agung. 2011. Hal 17,36

19. WHO. Prevention and Management of Osteoporosis.Genewa;2003: p.921-36

20. Alexander M, Knight Karla. Questions and Answers about Osteoporosis and Osteopenia.Best Practice and Research.2002. p: 20-25

21. Tandra H. Osteoporosis Mengenal, Mengatasi dan Mencegah Tulang Keropos. Jakarta:PT Gramedia Pustaka Utama.2009. Hal 11-12

22. May-Choo Wang, Patricia B Crawford, Mark Hudes, Marta Van Loan, Kirstin Siemering, and Laura K Bachrach. Diet In Midpuberty And Sedentary Activity In Prepuberty Predict Peak Bone Mass. Am J Clin Nutr 2003. Vol 77. P: 495503

23. Sankaran Balu. Osteoporosis Clinical, Radiological, Histological, Assesment and an Experimental Study.New Delhi.2000. p: 176-211

24. Bredella MA. Perspective: the bone-fat connection. Skeletal Radiol. 2010. Vol 39. P: 729-731

25. Rosen CJ and Klibanski A. Bone, Fat, and Body Composition: Evolving Concepts in the Pathogenesis of Osteoporosis. The American Journal of Medicine.May 2009. Vol 122. No 5. P: 409-414

26. Russell M, Mendes N, Miller KK, Rosen CJ, Lee $\mathrm{H}$, Klibanski A, et al. Visceral Fat Is a Negative Predictor of Bone Density Measures in Obese Adolescent Girls. J Clin Endocrinol Metab, March 2010.Vol 95(3).p: 1247-1255

27. Janicka A, Wren TAL, Sanchez MM, Dorey F, Kim PS, Mittelman SD, et al. Fat Mass Is Not Beneficial to Bone in Adolescents and Young Adults. The Journal of Clinical Endocrinology \& Metabolism.Vol 92(1).p: 143-147

28. Taylor ED, Theim KR, Mirch MC, Ghorbani S, Marian, Tanofsky-Kraff, et al. Orthopedic Complications of Overweight in Children and Adolescents. Pediatrics. 2006.Vol 117.p: 21672174

29. NIH Consensus Statement. Osteoporosis Prevention, Diangnosis, and Therapy. National Institute oh Health.Kensington.2000; Vol17

30. Chan KM, Anderson M, Lau EMC. Exercise interventions: Defusing the world's osteoporosis time bomb. Bulletin of the World Health Organization 2003.Vol 81.p: 827-830

31. Sardinha LB, Baptista F and Ekelund U. Objectively Measured Physical Activity and Bone Strength in 9-Year-Old Boys and Girls. Pediatrics 2008. Vol 122. P: 728-736

32. Loud KJ, Gordon CM, Micheli LJ, and Field AE. Correlates of Stress Fractures Among Preadolescent and Adolescent Girls. Pediatrics.2005. Vol 115. P: 399-406

33. Smiciklas WH, Catherine WE. Diet and Bone Health. American College of Sports Medicine.2003
34. Melvin WH. Nutrition For Health, Fitnes, and Sport. Mc Graw Hill Higher Education.2007. Eighth edition.

35. Karapanou O, Papadimitriou A. Determinants of Menarche. Karapanou and Papadimitriou Reproductive Biology and Endocrinology. 2010.Vol 8.Page 115-123

36. Kalkwarf HJ, Khoury JC, and Lanphear BP. Milk Intake During Childhood And Adolescence, Adult Bone Density, And Osteoporotic Fractures In US Women. Am J Clin Nutr 2003. Vol 77. Page257-265

37. Tucker KL, Morita K, Ning Qiao, Hannan MT, Cupples LA, and Kiel DP. Colas, But Not Other Carbonated Beverages, Are Associated With Low Bone Mineral Density In Older Women: The Framingham Osteoporosis Study. Am J Clin Nutr2006. Vol 84. Page 936-942

38. Libuda L, Alexy U,Remer T, Stehle P, Schoenau E, and Kersting M. Association Between Long-Term Consumption Of Soft Drinks And Variables of Bone Modeling And Remodeling In A Sample Of Healthy German Children And Adolescents. Am J Clin Nutr 2008. Vol 88. Page1670-1677 